\title{
Keefektifan Achievement Motivation Training untuk Meningkatkan Motivasi Berprestasi Siswa Sekolah Menengah Pertama
}

\author{
Edwindhana Mareza Putra ${ }^{1 *}$, Dany M. Handarini², Muslihati Muslihati \\ ${ }^{1}$ Program Studi Bimbingan dan Konseling, Fakultas Keguruan dan Ilmu Pendidikan, \\ Universitas Nahdlatul Ulama Sunan Giri, Jl. Jend. Ahmad Yani No. 10, Bojonegoro, Jawa Timur, Indonesia 62115 \\ ${ }^{2}$ Jurusan Bimbingan dan Konseling, Fakultas Ilmu Pendidikan, Universitas Negeri Malang \\ Jl. Semarang No. 5, Malang, Jawa Timur, Indonesia, 65145 \\ *Penulis koresponden, e-mail: edwindhana@gmail.com
}

Artikel diterima: 3 Juli 2018; direvisi: 8 April 2019; disetujui: 11 April 2019

\begin{abstract}
The particular study aimed to determine the effectiveness of achievement motivation training (AMT) in increasing the achievement motivation of junior high school students. The study used an interrupted time-series design which conducted on an intact group consisting of eight subjects. Data measurements carried out three times in the pre-test and post-test conditions with six forms of achievement motivation scale. The AMT intervention in the psychoeducation frame consists of two strategies, namely achievement thinking and action strategies which are carried out in 12 sessions. The results showed that there is a difference between achievement motivation scores before and after AMT interventions.
\end{abstract}

Keywords: achievement motivation; AMT; psychoeducation

\begin{abstract}
Abstrak: Penelitian ini bertujuan untuk mengetahui keefektifan achievement motivation training (AMT) dalam meningkatkan motivasi berprestasi siswa sekolah menengah pertama (SMP). Penelitian ini menggunakan desain interrupted time series yang dilakukan pada kelompok intak yang terdiri dari delapan subjek. Pengukuran data dilakukan sebanyak tiga kali pada kondisi pre-test dan kondisi post-test dengan enam bentuk skala motivasi berprestasi. Intervensi $A M T$ dalam bingkai psikoedukasi terdiri dari dua strategi yaitu achievement thinking dan action strategies yang dilakukan dalam 12 sesi pertemuan. Hasil menunjukkan terdapat perbedaan antara skor motivasi berprestasi sebelum dan sesudah diberikan intervensi $A M T$.
\end{abstract}

Kata kunci: motivasi berprestasi; AMT; psikoedukasi

\section{PENDAHULUAN}

Masa remaja (usia 12-14 tahun) merupakan masa dimana individu mengalami proses transisi dalam minat pendidikan, dari masa kanak-kanak akhir yang bergairah dalam bersekolah menjadi merasa bosan dan mengembangkan sikap menentang serta kritis terhadap tugas-tugas akademik pada masa remaja (Hurlock, 2001). Prestasi dan keberhasilan di sekolah yang diperoleh individu remaja, memberikan kepuasan pribadi dan ketenaran dalam kelompok sebayanya, serta membentuk identitas diri positif yang akan terus berkembang dan menetap hingga masa dewasa. Prestasi dan keberhasilan pada fase remaja juga menjadi titik tolak kesuksesan individu selama hidupnya. Namun, tidak dipungkiri bahwa di setiap sekolah selalu didapati sekelompok anak yang diberi label siswa bermasalah, pandai namun tidak berprestasi, lambat dalam belajar atau siswa yang berpotensi untuk dikeluarkan sekolah. Hal tersebut terjadi karena siswa tidak dibekali dengan seperangkat keterampilan yang sangat mendukung kinerja akademik. 
Meningkatkan kesiapan siswa menghadapi kehidupan perguruan tinggi tidak hanya dilakukan dengan membangun konten pengetahuan siswa dan keterampilan akademik, namun juga mengembangkan seperangkat faktor non-kognitif (tingkah laku; keterampilan; sikap dan strategi) yang sangat penting bagi kinerja akademik dan ketekunan pada pendidikan menengah (Nagaoka dkk., 2013). Perilaku dan kinerja akademik siswa dipengaruhi oleh berbagai komponen psikologis, dan motivasi merupakan salah satu komponen psikologis yang menjadi pondasi penting dalam perkembangan akademik siswa (Steinmayr \& Spinath, 2009).

Motivasi dalam konteks pendidikan disebut motivasi berprestasi yang berupa keinginan untuk menyelesaikan kegiatan akademik dengan sukses. Motivasi berprestasi adalah suatu usaha untuk mencapai hasil yang sebaik-baiknya dengan berpedoman pada suatu standar keunggulan tertentu (standards of excellence) (McClelland, 1961). Individu yang memiliki motivasi berprestasi tinggi, cenderung memperkirakan tugas yang akan dikerjakan; merasa tertantang; menunjukkan kerja keras; mengevaluasi diri; berorientasi jangka panjang serta bekerja demi kepuasan diri (keahlian dan pengakuan) (Martín-Albo dkk., 2012; Nakamura, 2009). Dapat dikatakan bahwa motivasi berprestasi berpengaruh terhadap kinerja dan keberhasilan akademik siswa, karena motivasi berprestasi merupakan prediktor yang berhubungan dengan prestasi belajar siswa (Hikmah, 2016; Mufaridah, 2016). Terbukti, beberapa penelitian menunjukkan adanya hubungan yang signifikan antara motivasi dan hasil belajar (Motaharinezhad dkk., 2016; Sumantri \& Whardani, 2017).

Studi pendahuluan yang dilakukan dengan mewawancarai guru bimbingan dan konseling (BK) SMP negeri di Malang menunjukkan bahwa sekolah yang mayoritas siswanya berlatarbelakang sosial ekonomi menengah ke bawah selalu berhadapan dengan rendahnya minat akademik, beberapa perilaku yang menunjukkan isu rendahnya motivasi dalam berprestasi adalah: mengerjakan tugas asal-asalan; mencontek tugas teman; tidak berusaha maksimal ketika ujian; dan tidak berminat saling berkompetisi dalam prestasi akademik. Rendahnya minat dan kinerja akademik yang bermuara kepada kegagalan akademik tersebut bermakna bahwa isu terkait motivasi berprestasi siswa harus menjadi perhatian penting.

Sering kali guru BK sangat ingin membantu siswa, namun guru BK menyadari bahwa dirinya tidak memahami motivasi yang melatarbelakangi perilaku siswa dan juga tidak dapat menentukan cara yang paling tepat untuk menghadapi isu motivasi (Rowell \& Hong, 2013). Layanan yang diberikan untuk meningkatkan motivasi berprestasi hendaknya tidak serta merta bersifat kuratif melalui konseling, tetapi lebih bersifat pengembangan. Psikoedukasi (bimbingan kelompok) merupakan metode layanan yang biasa digunakan dalam program BK komperehensif dengan tujuan untuk memaksimalkan potensi dalam perkembangan diri siswa yang sehat dan sukses (Geroski \& Kraus, 2002). Dalam bimbingan kelompok, peran guru BK bukan hanya sebagai helper yang bersifat kuratif. Guru BK juga berperan sebagai fasilitator dan psikoedukator yang bertanggungjawab dalam pengembangan aspek pribadi-sosial-emosional siswa, juga bertanggungjawab atas kinerja dan keberhasilan akademik siswa (Handarini, 2016).

Achievement motivation berkorelasi erat dengan hasil belajar. Sebuah intervensi yang telah terbukti mampu meningkatkan hasil belajar adalah $A M T$ (Kolb, 1965). AMT pertama kali dilakukan pada latar vocational yang berfokus pada motivasi berprestasi entrepreneurship, tepatnya pada kelompok pengusaha kecil dengan menggunakan cerita, strategi tingkah laku dan latihan goal setting secara individual yang berhasil meningkatkan aspek cognitive achievement (McClelland, 1961). Banyak penelitian yang menunjukkan pengaruh positif dari $A M T$, beberapa penelitian tersebut menunjukkan bahwa AMT mampu meningkatkan: motivasi (DeCharms, 1972; Smith, 1973); hasil belajar (DeCharms, 1972; Ryals, 1975); internal control (Lopez, 2008; Smith, 1973); motivasi intrinsik (Cueva, 2006); orientasi masa depan dan motivasi akademik (Iskandar dkk., 2014).

Beberapa penelitian yang telah dibahas menunjukkan bahwa $A M T$ dapat meningkatkan motivasi berprestasi melalui serangkaian sesi dengan menggunakaan strategi cognitive-behavioral. Metode eklektik yang bermuatan perkembangan diri dan kesejahteraan diri dalam $A M T$ tersebut memberikan peluang bagi siswa untuk menanamkan pemikiran berprestasi dan berlatih perilaku berprestasi. $A M T$ juga dipandang dapat menjadi salah satu layanan andalan dalam BK komprehensif di Indonesia yang berfokus pada perkembangan psikologis siswa terutama motivasi berpretasi. Berdasarkan berbagai hal tersebut, peneliti ingin mengetahui keefektifan $A M T$ untuk meningkatkan motivasi berprestasi pada siswa SMP. 


\section{METODE}

Penelitian ini menggunakan rancangan penelitian interrupted time series yang dilakukan pada kelompok intak. Kelompok intak terdiri dari delapan subjek dengan latar belakang status sosial ekonomi menengah ke bawah. Pengukuran data dilakukan sebanyak tiga kali pada kondisi pre-test dan kondisi post-test yang diukur dengan enam bentuk skala motivasi berprestasi (A, B, C, D, E, F). Setiap skala masing-masing memiliki 15 butir yang dikembangkan dari konstruk Prestatie Motivatie Test (Hermans, 1970). Intervensi $A M T$ terdiri dari dua strategi yaitu achievement thinking dan action strategies dilakukan dalam 12 sesi pertemuan yaitu: pertemuan 1: pembentukan, pertemuan 2-3 tahapan achievement syndrome, pertemuan 4-5 tahapan self study, pertemuan 6-8 tahapan game simulation, pertemuan 9-11 tahapan goal setting, dan pertemuan 12 penutup. Analisis data penelitian diawali dengan pernyortiran skor konsisten pada kondisi pre-test dan post-test, kemudian dilanjutkan analisis uji statistis Wilcoxon Sign Rank Test dan analisis grafik.

\section{HASIL}

Data hasil pengukuran pre-test (A-D-E) dan post-test (B-C-F) yang telah disortir berdasarkan konsistensi skor disajikan pada tabel 1 , tanda * pada angka di dalam tabel berarti skor konsisten. Hasil pre-test motivasi berprestasi secara kelompok menunjukkan rerata skor konsisten sebesar 51,125 hingga 52,125 yang berada pada kategori motivasi berprestasi sedang. Setelah diberikan intervensi $A M T$, diperoleh hasil post-test motivasi berprestasi secara kelompok menunjukkan peningkatan rerata skor konsisten sebesar 57 hingga 58,125 yang berada pada kategori motivasi berprestasi tinggi. Secara analisis statistik dengan uji Wilcoxon Sign Rank Test diperoleh z hitung sebesar -2,375 a dan nilai Asymp. Sig. (2-tailed) sebesar 0,018. Hasil uji hipotesis tersebut bermakna bahwa terdapat perubahan tingkat motivasi berprestasi pada subjek penelitian sebelum dan sesudah intervensi $A M T$.

Analisis tren terhadap rerata skor konsisten yang disajikan pada gambar 1 menunjukkan adanya: (1) tren kestabilan skor pre-test; (2) tren kestabilan skor post-test; dan (3) tren peningkatan setelah intervensi. Tren rerata skor pre-test menunjukkan adanya kecenderungan kestabilan skor dimana rerata pre-test 1 adalah 51,125 dan rerata pre-test 2 adalah 52,125. Kondisi pre-test tersebut menunjukkan adanya tren yang naik secara perlahan namun masih dalam kategori motivasi berprestasi sedang, yang berarti kedua skor pre-test tersebut stabil berada dalam kategori sedang.

Tren rerata skor post-test menunjukkan adanya kecenderungan kestabilan skor, yaitu rerata post-test 1 dengan skor 57 dan rerata post-test 2 dengan skor 58,125 . Kedua rerata post-test tersebut menunjukkan adanya tren yang naik secara perlahan namun masih dalam kategori yang sama yaitu motivasi berprestasi tinggi. Analisis tren hasil skor rerata pre-test dan post-test kelompok intervensi AMT menunjukkan adanya kenaikan tren yang cukup tajam. Terdapat peningkatan kategori dari rerata pre-test yang ada pada kategori sedang dengan skor 51,625 menjadi rerata post-test yang masuk kategori tinggi dengan skor 57,563. Berdasarkan hasil analisis tren, dapat diketahui bahwa terjadi peningkatan skor motivasi berprestasi sesudah diberikan intervensi $A M T$.

Tabel 1. Hasil Pre-test (A-D-E) dan Post-test (B-C-F)

\begin{tabular}{|c|c|c|c|c|c|c|c|c|c|c|c|c|}
\hline \multirow{3}{*}{$\begin{array}{c}\text { Subjek } \\
\text { VA }\end{array}$} & \multicolumn{6}{|c|}{ Pre-test } & \multicolumn{6}{|c|}{ Post-test } \\
\hline & \multicolumn{2}{|c|}{ Form A } & \multicolumn{2}{|c|}{ Form D } & \multicolumn{2}{|c|}{ Form E } & \multicolumn{2}{|c|}{ Form B } & \multicolumn{2}{|c|}{ Form C } & \multicolumn{2}{|c|}{ Form $\mathbf{F}$} \\
\hline & $51^{*}$ & Sedang & 65 & Tinggi & $55^{*}$ & Sedang & $58 *$ & Tinggi & 50 & Sedang & $61 *$ & Tinggi \\
\hline SPA & $54^{*}$ & Sedang & 67 & Tinggi & $48^{*}$ & Sedang & $61^{*}$ & Tinggi & $60 *$ & Tinggi & 50 & Sedang \\
\hline SW & $45^{*}$ & Sedang & 69 & Tinggi & $47 *$ & Sedang & $63^{*}$ & Tinggi & 50 & Sedang & $68^{*}$ & Tinggi \\
\hline MM & $53^{*}$ & Sedang & 60 & Tinggi & $56^{*}$ & Tinggi & $58^{*}$ & Tinggi & 53 & Sedang & $62 *$ & Tinggi \\
\hline DK & $55^{*}$ & Sedang & 68 & Tinggi & $56^{*}$ & & $57 *$ & Tinggi & 53 & Sedang & $56^{*}$ & Tinggi \\
\hline AR & $49 *$ & Sedang & 67 & Tinggi & $52 *$ & Sedang & 48 & Sedang & $51^{*}$ & Sedang & $52 *$ & Sedang \\
\hline RAH & 55 & Sedang & $52 *$ & Sedang & $50 *$ & Sedang & $56^{*}$ & Tinggi & 53 & Sedang & $55^{*}$ & Sedang \\
\hline AYM & $50 *$ & Sedang & 57 & Tinggi & $53 *$ & Sedang & $52 *$ & Sedang & 47 & Sedang & $51^{*}$ & Sedang \\
\hline
\end{tabular}




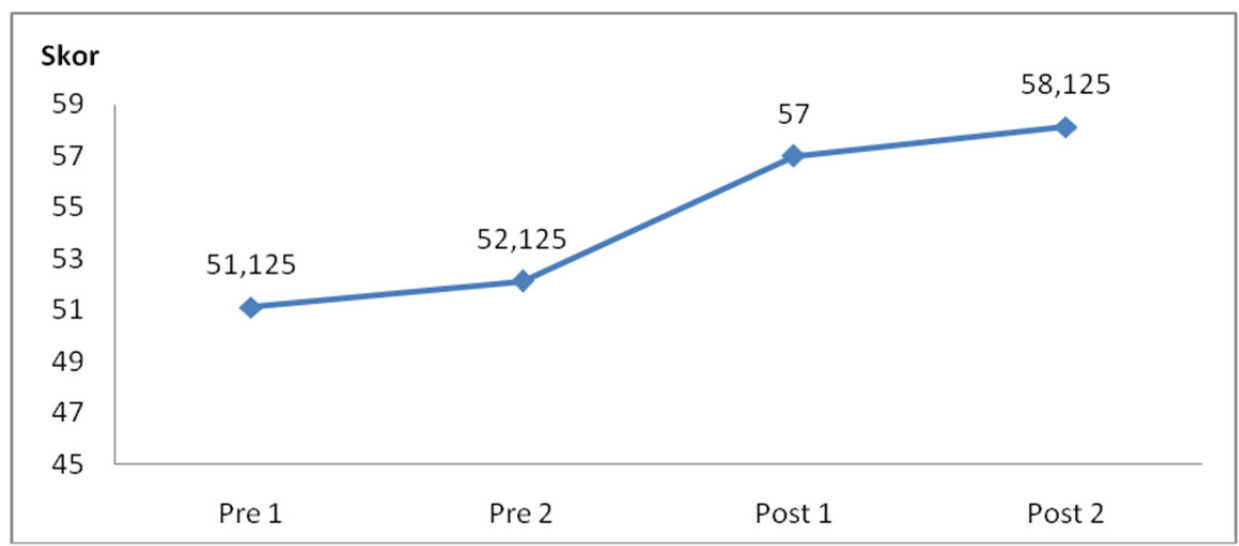

Gambar 1. Grafik Rerata Skor Konsisten Pre-test dan Post-test Kelompok

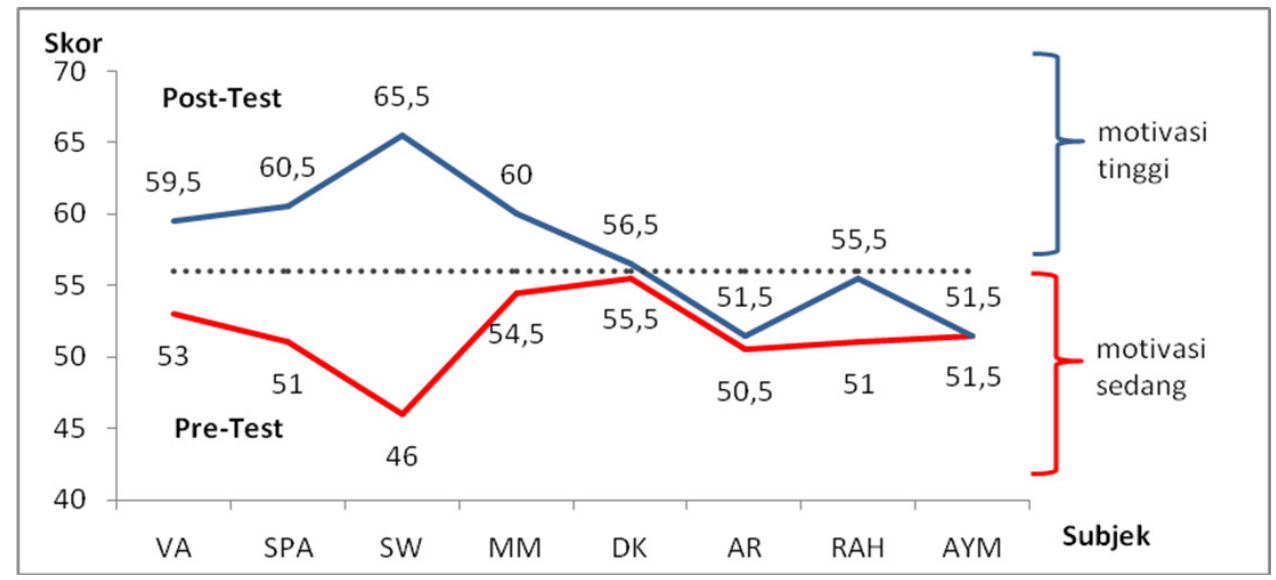

Gambar 2. Grafik Rerata Pre-test dan Post-test Subjek Penelitian

Gambar 2 menunjukkan bahwa delapan subjek penelitian mengalami perubahan motivasi berprestasi yang tidak terlalu signifikan. Dapat dikatakan bahwa $A M T$ memberikan perubahan yang berbeda-beda pada masing-masing subjek penelitian, lima subjek (VA; SPA; SW; MM; DK) mengalami peningkatan kategori motivasi berprestasi, dua subjek (AR; RAH) mengalami peningkatan skor motivasi berprestasi dan satu subjek (AYM) tidak mengalami peningkatan motivasi berprestasi.

\section{PEMBAHASAN}

Proses intervensi AMT dilakukan melalui empat tahap utama. Pertama, tahap achievement syndrome, yang mengajarkan partisipan mengetahui bagaimana individu dengan motivasi berprestasi tinggi berpikir, berbicara dan bertindak serta mengetahui kaitannya dengan kebutuhan untuk berprestasi (McClelland, 1961). Melalui identifikasi karakter sukses "Adam Khoo" dan peta motivasi berprestasi, kesadaran berprestasi karakter high $n$-ach dan penanaman pola pikir berprestasi siswa akan tumbuh. Tahap achievement syndrome pada intervensi AMT, sejalan dengan intervensi cognitive teaching dalam penelitian Smith (1973) yang bertujuan memberikan pemahaman konsep dan ide motivasi berprestasi pada pikiran siswa. Melalui penanaman pikiran berprestasi, siswa dapat mengembangkan pola pemikiran yang sama dengan individu pemilik motivasi berprestasi tinggi.

Tahap kedua $A M T$ adalah self-study yang memberikan kesempatan individu untuk memahami seperti apa dirinya dan ingin menjadi apa (McClelland, 1961). Pada komponen self-study, individu mengenali diri mereka lebih dalam, yang kemudian dapat mendorong pada perubahan diri ideal. Kegiatan pada tahap self-study, sejalan dengan inti intervensi DeCharms (1972) yang berfokus pada membangun konsep dan keyakinan diri melalui cerita deskripsi diri maupun intervensi yang berfokus pada locus of control (Lopez, 2008). Namun, pada penelitian ini pembentukan konsep diri dan keyakinan diri berprestasi melalui "kawan idola" dirasa kurang optimal karena terbentur belief subjek yang erat 
dengan faktor aspirasi orangtua dan status sosio-ekonomi dimana siswa berada, yang mengakibatkan kesulitan dalam menemukan dan mengidentifikasi role model berprestasi yang tepat di lingkungan (kelas/keluarga) siswa berada.

Tahap ketiga $A M T$ adalah tahap game simulation. Pada tahap ini, siswa mengalami proses berlatih perilaku berprestasi yang memberikan wadah bagi mereka untuk mengalami secara nyata kondisi yang mendukung perkembangan motivasi (McClelland \& Alschuler, 1971). Kondisi dan suasana pada game simulation melalui permainan dart dan origami mendorong subjek penelitian untuk lebih antusias mengkaitkan achievement thinking dalam gaya ekspresi perilaku yang tepat. Kegiatan pada game simulation sejalan dengan intervensi pada penelitian Kolb (1965) yang menggunakan permainan balap mobil dan bussiness game. Melalui simulasi permainan, siswa dapat belajar dengan mengalami secara langsung berbagai aspek motivasi berprestasi yang meliputi: (1) memahami pengambilan resiko; pencarian pengakuan; pemilihan teman; ketegangan menghadapi tugas; sudut pandang terhadap waktu; pemahaman terhadap waktu; kegigihan; (2) memahami penggunaan umpan balik; (3) dapat menetapkan tujuan menantang dan realistis; (4) serta menggunakan umpan balik untuk memperbaiki kinerja.

Keempat adalah tahap goal setting. Tahap ini membantu siswa mengadopsi achievement thinking pada setting di luar kelompok sesuai dengan kehidupan nyata siswa, yaitu pada kegiatan menyusun tujuan yang realistis bagi diri mereka sendiri (McClelland, 1969). Inti komponen goal setting sejalan dengan penelitian yang berfokus pada orientasi masa depan (Iskandar dkk., 2014) dan penelitian lain yang berfokus pada goal orientation (Cueva, 2006). Pada proses ini, subjek diajak untuk: (1) mengetahui dan menyusun arah tujuan hidup sukses yang diinginkan; (2) mengantisipasi hambatan dan memperjelas arah tindakan dalam mencapai tujuan dengan mengidentifikasi hambatan (dalam diri dan luar diri) serta menyusun rencana tindakan; (3) mampu menggunakan balikan yang konkrit dengan membuat dan menggunakan tabel talis serta grafik untuk memperkuat komitmen dan memperbaiki kinerja mencapai tujuan. Dengan demikian, subjek menjadi lebih menyadari sejauh mana perkembangan pencapaian tujuan dan seberapa baik kinerja yang telah ia dilakukan.

Pada penelitian ini, AMT secara statistik telah terbukti dapat meningkatkan motivasi berprestasi, namun jika diamati dan dianalisis secara individual berdasarkan rerata dan trend kestabilan skor motivasi berprestasi, ditemukan delapan subjek penelitian yang tidak mengalami perubahan yang sangat signifikan pada motivasi berprestasi. Dapat dikatakan, AMT memberikan perubahan yang berbedabeda pada masing-masing subjek. Lima subjek mengalami peningkatan kategori motivasi berprestasi, dua subjek mengalami peningkatan skor motivasi berprestasi dan satu subjek stabil tidak mengalami peningkatan motivasi berprestasi. Hasil analisis individual menunjukkan bahwa tingkat motivasi berprestasi subjek tidak mengalami perubahan skor yang sangat signifikan dan datanya cenderung fluktuatif. Hal ini disebabkan karena motivasi berprestasi sebagai variabel terikat memiliki variabel moderasi yaitu aspirasi orangtua dan status sosial ekonomi.

Secara tidak langsung ditemukan adanya variabel moderasi berupa nilai ekspektasi (harapan) sebagai bentuk aspirasi orangtua yang ditanamkan menjadi belief pada diri anak. Aspirasi orangtua dapat dipahami sebagai standar bagi kinerja yang diatur, dikomunikasikan dan dilakukan secara langsung oleh orangtua terhadap anaknya (Wentzel, 1994). Aspirasi orangtua yang berperan sebagai orientasi motivasional bagi anak merupakan prediktor bagi keberhasilan akademik dan memiliki hubungan signifikan terhadap penetapan tujuan akademik serta kegigihan di sekolah (Bronstein dkk., 2005; Wang \& Neihart, 2015). Hal ini sejalan hasil penelitian yang menunjukkan motivasi berprestasi pada budaya siswa Indonesia cenderung menganut nilai menekankan kepatuhan untuk memenuhi ekspektasi sosial (terutama orangtua) terhadap pencapaian tujuan akademik di sekolah (Liem \& Nie, 2008). Subjek dalam penelitian ini meyakini aspirasi orangtua dan menerapkannya sebagai standar yang lebih memprioritaskan vokasi di masa depan namun kurang memprioritaskan pencapaian keberhasilan akademik saat ini di sekolah.

Sama halnya dengan peran variabel moderasi status sosial ekonomi yang terlihat pada skor pengukuran kondisi pre-test dan post-test kedelapan subjek yang menggambarkan ketidakstabilan atau fluktuasi tingkat motivasi. Data fluktuatif ini memiliki kesamaan dengan data temuan Kolb (1965), yaitu tingkat motivasi yang ditunjukkan melalui rerata nilai belajar yang fluktuatif meningkat pada kelompok $A M T$ berlatarbelakang sosio-ekonomi bawah, sedangkan rerata nilai belajar meningkat tajam stabil pada kelompok $A M T$ subjek berlatar belakang sosio-ekonomi atas. Peranan variabel moderasi status 
sosial ekonomi ini sejalan dengan hasil survei yang menemukan bahwa siswa dari keluarga status sosial ekonomi menengah ke bawah cenderung memiliki motivasi berprestasi lebih rendah dan tidak stabil jika dibandingkan siswa dari status sosial ekonomi menengah ke atas (OECD, 2017).

Siswa dengan status sosio-ekonomi atas mengalami tuntutan untuk berprestasi dan melakukan yang terbaik di sekolah, sedangkan siswa dengan status sosio-ekonomi menengah ke bawah tidak mengalami tuntutan yang sama (Kolb, 1965). Dapat dikatakan, latarbelakang status sosio-ekonomi lingkungan siswa berperan memberikan tekanan dan ekspektasi sosial (aspirasi sosial) yang mendorong adanya perubahan subculture (budaya internal) pada siswa yang berupa nilai keinginan untuk berprestasi akademik di sekolah. Siswa dari status sosio-ekonomi menengah ke bawah yang telah mengikuti summer camp $A M T$ dan kembali ke lingkungannya (kondisi tidak ada tuntutan berprestasi) tidak mengalami banyak perubahan subculture untuk berprestasi (Kolb, 1965). Hal ini dimaknai bahwa status sosio-ekonomi merupakan tempat asal aspirasi sosial yang mendukung ada/tidaknya perubahan subculture berupa kesadaran terhadap keinginan berprestasi yang bermuara pada perubahan motivasi berprestasi.

Meningkatkan motivasi berprestasi berarti menanamkan jiwa Hermes-simbol motivasi berprestasi dalam mitologi pada diri individu (Alschuler, 1973). Peningkatan motivasi berprestasi dapat bermakna bahwa telah terinternalisasikannya achievement thinking dan mulai diterapkannya achievement behavior untuk mencapai kriteria/standar keberhasilan yang ia tetapkan. Dickhäuser \& Rheinberg (2003) mengemukakan bahwa penetapan standar keberhasilan mengacu pada tiga norma yaitu: (1) norma individual: individu akan membandingkan kinerjanya dengan hasil sebelumnya untuk menentukan apakah kinerjanya mengalami peningkatan, penurunan atau tidak berubah; (2) norma sosial: individu akan membandingkan kinerjanya dengan hasil kinerja orang lain; (3) norma objektif: individu akan mengukur hasil kinerja berdasarkan kriteria absolut yang melekat pada tugas tersebut. Individu yang telah menginteralisasikan cara berpikir dan bertindak berprestasi secara sadar menerapkan tiga norma ketika menetapkan standar keberhasilan. Dengan demikian, individu yang memiliki motivasi berprestasi tinggi akan mengalami proses self-evaluation yang dinamis pada standar keberhasilannya sehingga memunculkan perubahan subculture dan dorongan untuk berusaha memperbaiki kinerja guna mencapai tujuan berhasilnya.

\section{SIMPULAN}

$A M T$ secara statistik telah terbukti dapat meningkatkan motivasi berprestasi. Namun, hasil analisis secara individual menunjukkan perubahan motivasi berprestasi yang kurang signifikan. Kurang signifikannya perubahan tersebut disebabkan oleh pengaruh aspirasi orangtua dan status sosial ekonomi subjek. Agar motivasi berprestasi meningkat secara signifikan dan stabil, diperlukan dua kondisi, yaitu: (1) aspirasi orangtua yang menekankan keberhasilan dan kinerja akademik yang baik selama siswa bersekolah; serta (2) tersedianya lingkungan yang memfasilitasi adanya perubahan subculture berupa kesadaran untuk berprestasi di sekolah. Intervensi $A M T$ juga memerlukan kolaborasi antara guru BK dan guru mata pelajaran serta dilakukan tindak lanjut berupa layanan advokasi.

\section{DAFTAR RUJUKAN}

Alschuler, A. S. (1973). Developing Achievement Motivation in Adolescents: Education for Human Growth. Educational Technology.

Bronstein, P., Ginsburg, G. S., \& Herrera, I. S. (2005). Parental Predictors of Motivational Orientation in Early Adolescence: A Longitudinal Study. Journal of Youth and Adolescence, 34(6), 559-575.

Cueva, C. (2006). An Achievement Motivation Program for Young Minority Students Utilizing CognitiveBehavioral Techniques. Texas A\&M University-Corpus Christi.

DeCharms, R. (1972). Personal Causation Training in the Schools. Journal of Applied Social Psychology, 2(2), 95-113. https://doi.org/10.1111/j.1559-1816.1972.tb01266.x

Dickhäuser, O., \& Rheinberg, F. (2003). Bezugsnormorientierung: Erfassung, Probleme, Perspektiven. Diagnostik von Motivation Und Selbstkonzept, 41-55.

Geroski, A. M., \& Kraus, K. L. (2002). Process and Content in School Psychoeducational Groups. Journal for Specialists in Group Work, 27(2), 233-245. 
Handarini, D. M. (2016). Pengaruh Aspek Non-kognitif pada Kinerja dan Keberhasilan Akademik Siswa dan Implikasinya pada Peran Konselor di Sekolah. Dalam Seminar Nasional Bimbingan dan Konseling Pascasarjana Universitas Negeri Malang. Malang.

Hermans, H. J. (1970). A Questionnaire Measure of Achievement Motivation. Journal of Applied Psychology, 54(4), 353-363. https://doi.org/10.1037/h0029675

Hikmah, O. N. (2016). Model Empiris Hubungan Faktor Prestasi Akademik Siswa SMA High Achiever di Kota Malang. Universitas Negeri Malang.

Hurlock, E. B. (2001). Psikologi Perkembangan: Suatu Pendekatan Sepanjang Rentang Kehidupan. Jakarta: Erlangga.

Iskandar, Y. R., Novianti, L. E., \& Siswanto, S. Y. (2014). The Role of Achievement Motivation Training ModelBased on e-Learning to Clarify Future Education Orientation of Adolescent in Jatinangor. Dalam International Conference on Education and e-Learning (EeL). Proceedings (p. 9). Global Science and Technology Forum.

Kolb, D. A. (1965). Achievement Motivation Training for Underachieving High-School Boys. Journal of Personality and Social Psychology, 2(6), 783-792. https://doi.org/10.1037/h0022787

Liem, A. D., \& Nie, Y. (2008). Values, Achievement Goals, and Individual-Oriented and Social-Oriented Achievement Motivations among Chinese and Indonesian Secondary School Students. International Journal of Psychology, 43(5), 898-903.

Lopez, B. J. (2008). The Efficacy of An Achievement Motivation Program. Texas A\&M University-Corpus Christi.

Martín-Albo, J., Núñez, J. L., Domínguez, E., León, J., \& Tomás, J. M. (2012). Relationships between Intrinsic Motivation, Physical Self-Concept and Satisfaction with Life: A Longitudinal Study. Journal of Sports Sciences, 30(4), 337-347. https://doi.org/10.1080/02640414.2011.649776

McClelland, D. C. (1969). The Role of Educational Technology in Developing Achievement Motivation. Educational Technology, 9(10), 7-16.

McClelland, D. C., \& Alschuler, A. S. (1971). Achievement Motivation Development Project. Final Report. ERIC.

McClelland, D. C. (1961). The Achieving Society. New York: D Van Nostrand Company. https://doi. org/10.1037/14359-000

Motaharinezhad, F., Seyed, S., Rezaye, A., Heidarieh, S. M., \& Noruzi, R. (2016). Relationship between SelfEfficacy, Achievement Motivation and Academic Achievement in Students with Learning Disabilities. Journal of Mazandaran University of Medical Sciences, 25(132), 329-333.

Mufaridah, H. (2016). Model Teoretik Prestasi Akademik Siswa SMA Negeri Kota Malang. Universitas Negeri Malang.

Nagaoka, J., Farrington, C. A., Roderick, M., Allensworth, E., Keyes, T. S., Johnson, D. W., \& Beechum, N. O. (2013). Readiness for College: The Role of Noncognitive Factors and Context. Voices in Urban Education, $38,45-52$.

Nakamura, E. (2009). Relationship Between Nurses' Learning Motivation Inside/Outside the Workplace and Job/ Life Satisfaction. Journal of UOEH, 31(4), 377-387. https://doi.org/10.7888/juoeh.31.377

OECD. (2017). PISA 2015 Results: Students' Well-Being (Vol. 3. PISA in focus). OECD Publishing.

Rowell, L., \& Hong, E. (2013). Academic Motivation: Concepts, Strategies, and Counseling Approaches. Professional School Counseling, 16(3), 2156759X1701600301.

Ryals, K. (1975). Achievement Motivation Training for Low-Achieving Eighth and Tenth Grade Boys. The Journal of Experimental Education, 44(2), 47-51.

Smith, R. (1973). Achievement Motivation and Achievement Motivation training. Dalam R. Smith \& G. Walz (Eds.), Developing Students' Potentials (hal. 5-17). Washington,DC: Education Resources Division Capitol Publications, Inc.

Steinmayr, R., \& Spinath, B. (2009). The Importance of Motivation As A Predictor of School Achievement. Learning and Individual Differences, 19(1), 80-90.

Sumantri, M. S., \& Whardani, P. A. (2017). Relationship between Motivation to Achieve and Professional Competence in the Performance of Elementary School Teachers. International Education Studies, 10(7), $118-125$.

Wang, C. W., \& Neihart, M. (2015). How Do Supports From Parents, Teachers, and Peers Influence Academic Achievement of Twice-Exceptional Students. Gifted Child Today, 38(3), 148-159. https://doi. org/10.1177/1076217515583742

Wentzel, K. R. (1994). Family Functioning and Academic Achievement in Middle School A Social-Emotional Perspective. The Journal of Early Adolescence, 14(2), 268-291. 